\title{
DESAIN ALTERNATIF PERENCANAAN GEOMETRIK DAN PERKERASAN JALAN PADA RUAS JALAN PUNCAK - CIPANAS KM BANDUNG 85-87 KAB.CIANJUR PROVINSI JAWA BARAT
}

\author{
Oleh : \\ Yudi Sekaryadi \\ Dani Wardani \\ Program Studi Teknik Sipil \\ Fakultas Teknik Universitas Suryakancana
}

\begin{abstract}
ABSTRAK
Permasalahan lalu lintas dibeberapa kota di Indonesia pada beberapa dasawarsa terakhir ini sudah mencapai tahap yang sangat serius. Hal ini akibat dari meningkatnya volume lalulintas yang cukup pesat akibat laju aktifitas manusia. Oleh karena itu dituntut adanya prasarana transportasi jalan yang layak yang dapat menjamin keselamatan dan kenyamanan bagi pemakainya.Dengan demikian banyak permasalahan yang terjadi di ruas jalan Cipanas-Puncak ini, bukan hanya rusaknya jalan akibat meningkatnya kendaraan-kendaraan berat yang melintas akan tetapi sering terjadinya kecelakaan yang terjadi akibat bentuk jalan yang menurun dari arah Puncak serta menanjak dari arah Cipanas membuat pengguna jalan semakin khawatir dengan kondisi jalan yang terjadi saat ini.

Pada tugas akhir mendesain alteratif perencaaan geometrik dan perkerasan jalan pada ruas jalan Puncak-Cianjur Km.85s/d Km. 87, maka didapat lalu lintas harian rata-rata dari arah Puncak- Cianjur 11680 kend/hari sedangakan untuk Cianjur-Puncak $10728 \mathrm{kend} / \mathrm{hari}$. Dengan kecepatan rencana $60 \mathrm{~km} / \mathrm{jam}$, direncanakan 3 tikungan ( 2 tikungan Spiral-Circle-Spiral dan 1 tikungan Full Circle). Dan untuk lapisan perkerasan jalan baru di gunakan Laston (MS 744kg) dengan ketebalan $10 \mathrm{~cm}$, pondasi batu pecah kelas A dengan ketebelan $25 \mathrm{~cm}$, pondasi bawah sirtu kelas A dengan ketebalan 40cm dan CBR tanah dasar dengan DDT 2,75. Perkerasan jalan baru sepanjang $1.100 \mathrm{~m}$.
\end{abstract}

Kata kunci :, geometrik, tikungan, perkerasan

\section{A. PENDAhuluan}

Dalam mendukung perkembangan Permasalahan lalu lintas dibeberapa kota di Indonesia pada beberapa dasawarsa terakhir ini sudah mencapai tahap yang sangat serius. Hal ini akibat dari meningkatnya volume lalulintas yang cukup pesat akibat laju aktifitas manusia. Oleh karena itu dituntut adanya prasarana transportasi jalan yang layak yang dapat menjamin keselamatan dan kenyamanan bagi pemakainya.

Khususnya di kab Cianjur ini banyak sekali prasarana jalan yang rusak dan butuh perencanaan ulang prasarana jalan. Salah satu contoh yang akan dijadikan bahan tulisan oleh penulis yaitu jalan yang menghubungkan daerah ruas jalan raya Cipanas-Puncak KM Bandung 85-87 Kab Cianjur Provinsi Jawa Barat.

Jalan raya Cipanas-Puncak termasuk pada jalan arteri jalan yang melayani angkutan utama dengan ciri-ciri perjalanan jarak jauh, kecepatan rata-rata tinggi, dan jumlah jalan masuk dibatasi secara efisien. Pada ruas jalan ini. keadaan geografis serta medan ruas jalan tersebut yang menanjak dari arah Cipanas dan menurun curam dari arah Puncak menambah lagi malasah kenyamanan bagi pengguna jalan tersebut. Ditambah sering terjadinya kecelakaan akibat rem blong dikarenakan kendaraan-kendaraan besar yang memuat beban berlebih tidak bisa mengendalikan kendaraannya. Dengan demikian banyak permasalahan yang terjadi di ruas jalan CipanasPuncak ini, bukan hanya rusaknya jalan akibat meningkatnya kendaraan-kendaraan berat yang melintas akan tetapi sering terjadinya kecelakaan yang terjadi akibat bentuk jalan yang menurun dari arah Puncak serta menanjak dari arah Cipanas membuat pengguna jalan semakin khawatir dengan kondisi jalan yang terjadi saat ini.

\section{B. METODOLOGI PENELITIAN}

Dalam penelitian terdapat beberapa sumber data yaitu diantaranya adalah data primer dan data sekunder. Data primer yaitu data yang didapat dari hasil survey lapangan, yaitu survey volume kendaraan untuk memperoleh data lalu lintas harian rata-rata (LHR) dan foto visual tebing, lembah, turunan, tanjakan dan tikungan pada ruas jalan Cipanas-Puncak. Data LHR di gunakan dalam merencanakan tebal jalan. Data sekunder 
merupakan data yang diperoleh dari instansi yang terkait, diantaranya: Peta kontur jalan CipanasPuncak KM BDG 85-87 BAKOSURTANAL (Badan Koordinator Survey dan Pemetaan Nasional). Data CBR, ata CBR tanah untuk ruas jalan Cipanas-Puncak didapat dari Dinas Bina Marga Provinsi Cianjur.

Metode Analisa, untuk perencanaan geometrik mengacu ke Tata cara perencanaan geometrik jalan antar kota yang di terbitkan oleh Departemen Pekerjaan Umum Direktorat Jendral Bina Marga, Sep 1997. Dan untuk analisa tebal perkerasan yang akan digunakan dalam penelitian ini dengan menggunakan metode analisa komponen.

\section{ANALISIS DATA}

\section{Perencanaan Geometrik Jalan}

a) Penentapan Trase Jalan Baru

Peta topografi skala 1:25.000 dibuat trase jalan rencana, trase digambar dengan memperhatikan kontur tanah yang ada.

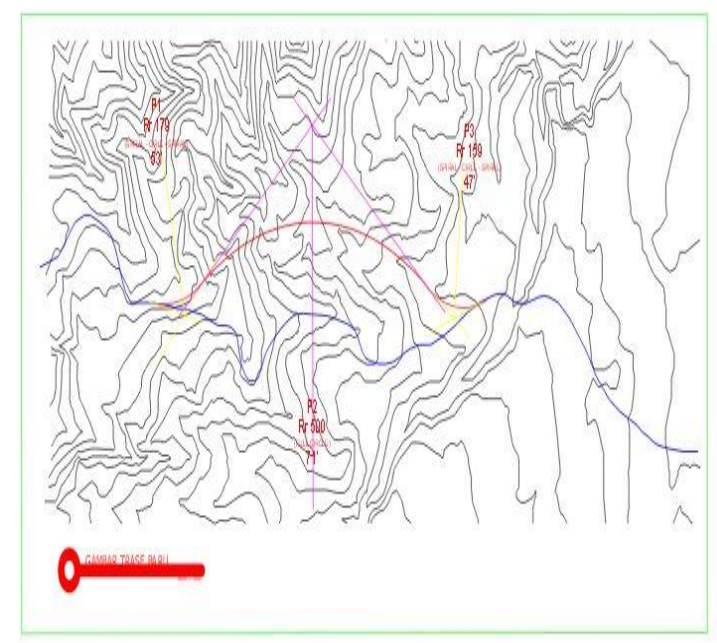

Gambar 4.1 Gambar Trase Lama Peta Topografi skala 1:25.000

Sumber: penulis Keterangan : Panjang jarak Trase baru $1100 \mathrm{~m}$

Data Perencanaan

a. Klasifikasi Jalan = pegunungan

b. Fungsi Jalan = Arteri Kelas III A (MST) 10 ton)

c. Tipe Jalan = 1 Jalur 2 Lajur 1 Arah $(2 / 1 \mathrm{~TB})$

d. Kecepatan Rencana $(\mathrm{Vr})=60 \mathrm{Km} / \mathrm{jam}$

e. Lebar perkerasan $(\mathrm{w})=2 \times 3,5 \mathrm{~m}$

f. Bahu jalan $\quad=2 \mathrm{~m}$

g. Jari-jari minimum $=159$ (untuk $\mathrm{Vr} 60$ $\mathrm{Km} / \mathrm{jam}$ )

h. e $\max =8 \%$

i. $\mathrm{e} \min =2 \%$
j. $\quad \Delta \mathrm{P} 1$
$=53^{0}$
k. $\Delta \mathrm{P} 2$
$=71^{0}$
1. $\Delta \mathrm{P} 2$
$=47^{0}$
$\mathrm{f}$ maks $\rightarrow$ koefisien gesek maksimun untuk perkerasan aspal.

Untuk VR $<80 \mathrm{Km} / \mathrm{jam} \rightarrow$ fmax $=(-0,00065 \mathrm{x}$ VR) $+0,192$

Untuk VR $>80 \mathrm{Km} /$ jam $\rightarrow$ fmax $=(-0,000125 \mathrm{x}$ VR) $+0,24$

$f$ maks $=(-0,00065 \times 60)+0,024=0,153$

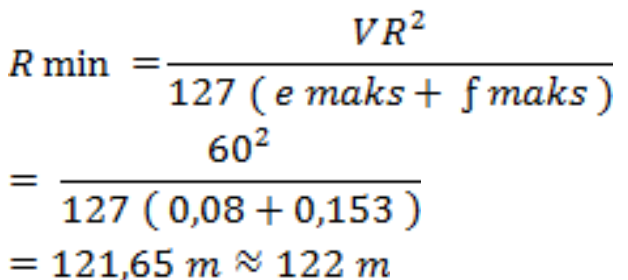

$D$ maks $=\frac{181913,53 \times(e \text { maks }+f \text { maks })}{V r^{2}}$

$=\frac{181913,53 \times(0,08+0,153)}{60^{2}}$

$$
=12,78^{\circ}
$$

Direncanakan geometric untuk daerah pegunungan

Tabel 4.1 hasil perhitungan tikungan $\mathrm{P} 1, \mathrm{P} 2$, dan

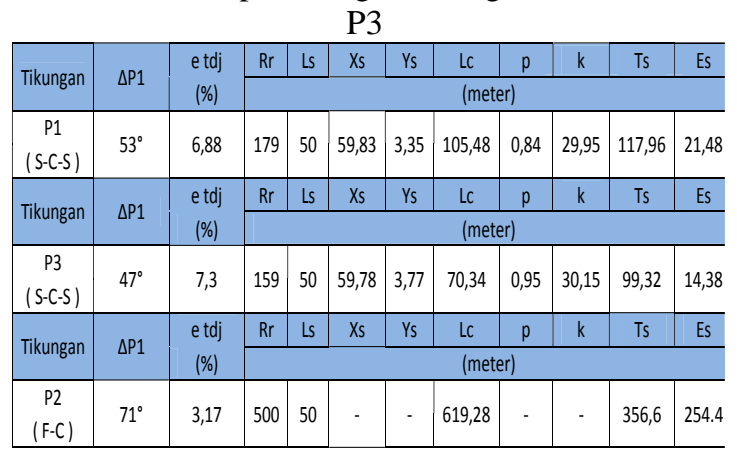

Syarat $L$ total $<2$ Ts

\begin{tabular}{|c|c|c|c|}
\hline Tikungan & P1 & P2 & P3 \\
\hline L total & 205,48 & 619,28 & 170,34 \\
\hline 2 Ts & 235,92 & 713,3 & 198,64 \\
\hline Keterangan & $\begin{array}{c}\text { memenuhi } \\
\text { syarat }\end{array}$ & $\begin{array}{c}\text { memenuhi } \\
\text { syarat }\end{array}$ & $\begin{array}{c}\text { memenuhi } \\
\text { syarat }\end{array}$ \\
\hline
\end{tabular}

Sumber : Pengolahan Data

Tabel 4.2 Pelebaran jalan tikungan P1, P2, dan P3 Rekapitulasi Pelebaran Jalan ditiap-tiap tikungan

\begin{tabular}{|c|c|}
\hline Tikungan & $\begin{array}{c}\text { Pelebaran } \\
\text { ( meter })\end{array}$ \\
\hline P1 ( S-C-S ) & 1,68 \\
\hline P2 ( F-C $)$ & 0,5 \\
\hline P3 ( S-C-S ) & 1,88 \\
\hline
\end{tabular}


Sumber : Pengolahan Data

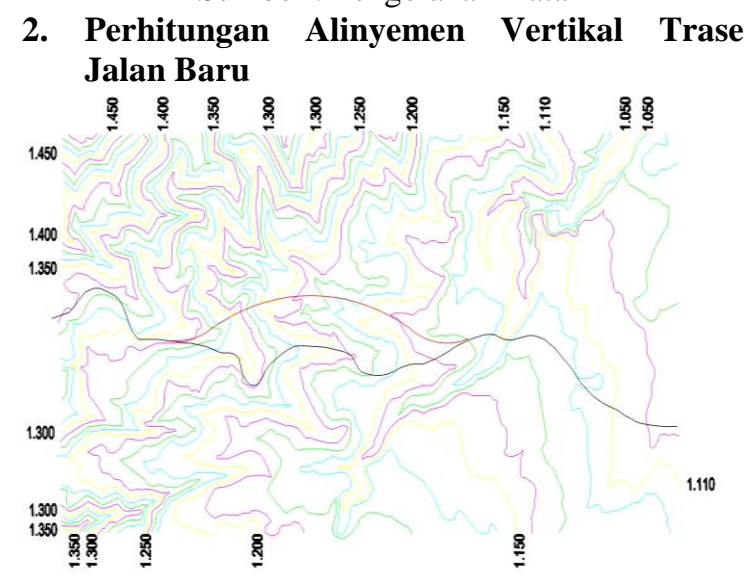

Gambar 4.5 Gambar Kontur dan Trase jalan yang ditinjau

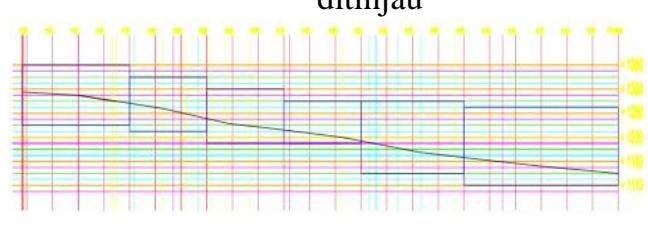

Gambar 4.6 Gambar Potongan Kontur dan Trase jalan yang ditinjau

Tabel 4.3 Rekapitulasi Perhitungan Vertikal

\begin{tabular}{|l|l|}
\hline STA & $\begin{array}{l}\text { ELEVASI } \\
\text { VERTICAL } \\
(\mathrm{m})\end{array}$ \\
\hline $0+050$ & 1159.87 \\
\hline $0+100$ & 1156.14 \\
\hline $0+150$ & 1153.41 \\
\hline $0+189.25$ & 1151.96 \\
\hline $0+200$ & 1148.09 \\
\hline $0+250$ & 1152.62 \\
\hline $0+300$ & 1158.64 \\
\hline $0+350$ & 1192.09 \\
\hline $0+400$ & 1185.81 \\
\hline $0+432,4$ & 1182.27 \\
\hline $0+450$ & 1182.00 \\
\hline $0+500$ & 1189.79 \\
\hline $0+550$ & 1211.49 \\
\hline $0+584,8$ & 1207.81 \\
\hline $0+600$ & 1208.89 \\
\hline $0+650$ & 1215.54 \\
\hline $0+700$ & 1233.09 \\
\hline $0+743,78$ & 1227.37 \\
\hline $0+750$ & 1228.29 \\
\hline $0+800$ & 1234.68 \\
\hline $0+850$ & 1270.64 \\
\hline $0+890$ & 1418.98 \\
\hline & \\
\hline 0
\end{tabular}

\begin{tabular}{|l|l|}
\cline { 2 - 2 } $0+900$ & 1263.46 \\
\hline $0+950$ & 1275.43 \\
\hline $1+000$ & 1286.36 \\
\hline $1+025,77$ & 1283.15 \\
\hline $1+050$ & 1287.63 \\
\hline $1+100$ & 1293.62 \\
\hline $1+150$ & 1300.61 \\
\hline
\end{tabular}

\section{Perhitungan Galian dan Timbunan}

Pekerjaan galian dan timbunan di sesuaikan dengan gambar yang direncanakan, semua ukuran yang tercantum dalam rencana ini dinyatakan dalam $\mathrm{mm}$, $\mathrm{cm}$, dan m. Permukaan atas lantai $(0+00)$ adalah sesuai dengan gambar

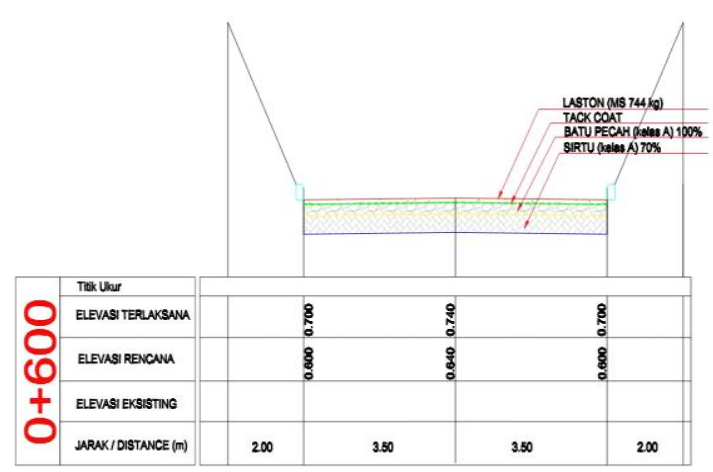

Gambar 4.10 Cross Section 0+600

- $\quad$ STA $0+600$

m. Luas penampang $=\mathrm{t}(\mathrm{b}+\mathrm{k} . \mathrm{t})$

n. $k=\sqrt{B^{2}+t^{2}}$

$k=\sqrt{2^{2}+0,69^{2}}$

o. $k=2,11$

$\mathrm{p}$.

$\mathrm{L}=0,69(7+2,11.0,69)$

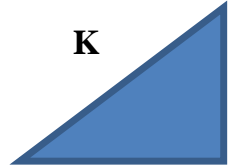

B
$\mathrm{L}=5.84 \mathrm{~m}$

- $\quad$ STA $0+650,(\mathrm{~L}=5.84 \mathrm{~m})$

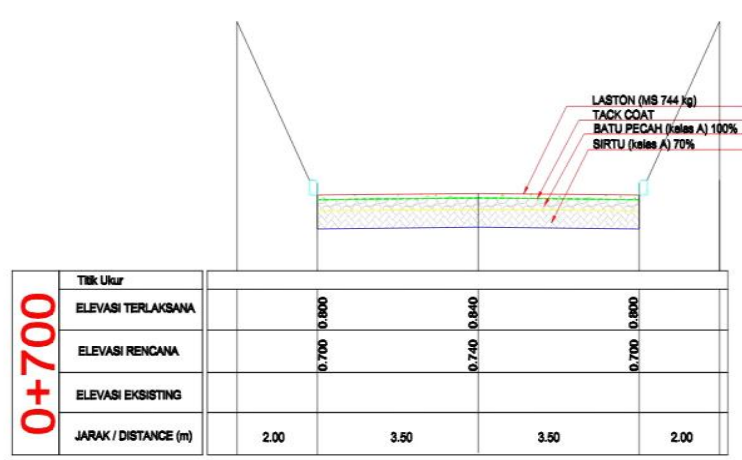

Gambar 4.11 Cross Section 0+700 
- $\quad$ STA 0+700

q. Luas penampang $=\mathrm{t}(\mathrm{b}+\mathrm{k} . \mathrm{t})$

r. $k=\sqrt{B^{2}+t^{2}}$

s. $k=\sqrt{2^{2}+1,07^{2}}$

s. $k=2,29$

$\mathrm{t}$. $=\mathrm{t}(\mathrm{b}+\mathrm{k} \cdot \mathrm{t})$

$\mathrm{L}=1,07(7+2,27$. 1,07)

$\mathrm{L}=10,09 \mathrm{~m}$

- $\quad$ STA $0+700,(\mathrm{~L}=10,09 \mathrm{~m})$

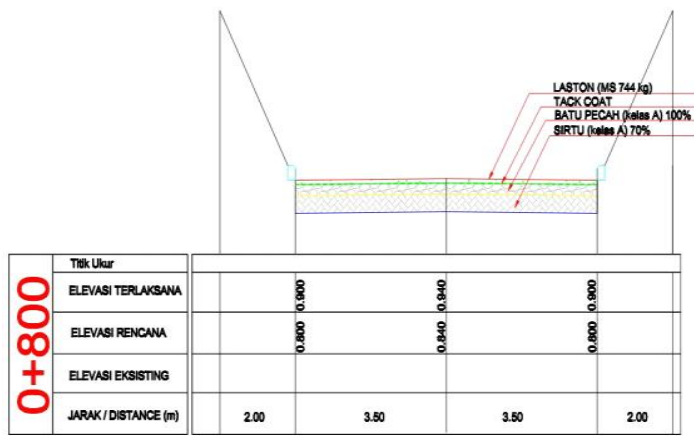

Gambar 4.12 Cross Section 0+800

- $\quad$ STA $0+800$

u. Luas penampang $=\mathrm{t}(\mathrm{b}+\mathrm{k} . \mathrm{t})$

$k=\sqrt{B^{2}+t^{2}}$

w. $k=\sqrt{2^{2}+1,79^{2}}$

$k=2,68$

$\mathrm{L}$. $=\mathrm{t}(\mathrm{b}+\mathrm{k} \cdot \mathrm{t})$

$\mathrm{L}=1,79(7+2,68$.1,79)

$\mathrm{L}=21,13 \mathrm{~m}$

- $\quad$ STA $0+850,(\mathrm{~L}=21,13)$

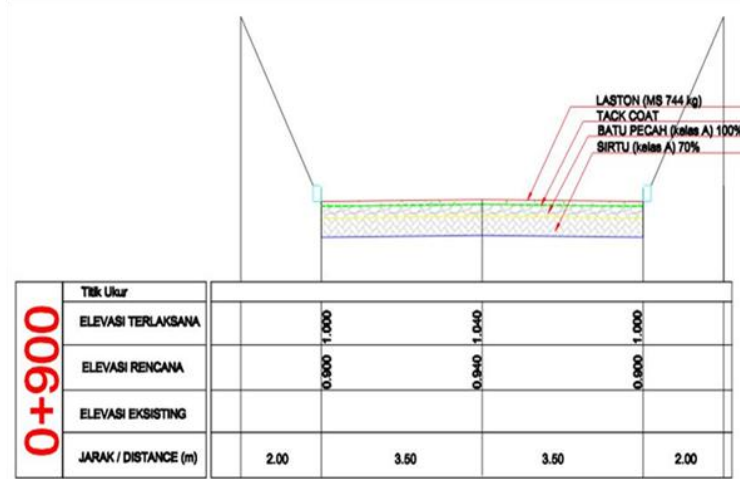

Gambar 4.13 Cross Section 0+900

- $\quad$ STA $0+900$

y. Luas penampang $=t(b+k . t)$

z. $\begin{aligned} & k=\sqrt{B^{2}+t^{2}} \\ & \text { aа. }\end{aligned}=\sqrt{2^{2}+2,19^{2}}$ bb. $k=2,97$

$\mathrm{L}=\mathrm{t}(\mathrm{b}+\mathrm{k} \cdot \mathrm{t})$

$\mathrm{L}=2,19(7+2,97.2,19)$

$\mathrm{L}=2 \mathrm{9}, 55 \mathrm{~m}$

- $\quad$ STA 0+950, $(\mathrm{L}=29,55 \mathrm{~m})$

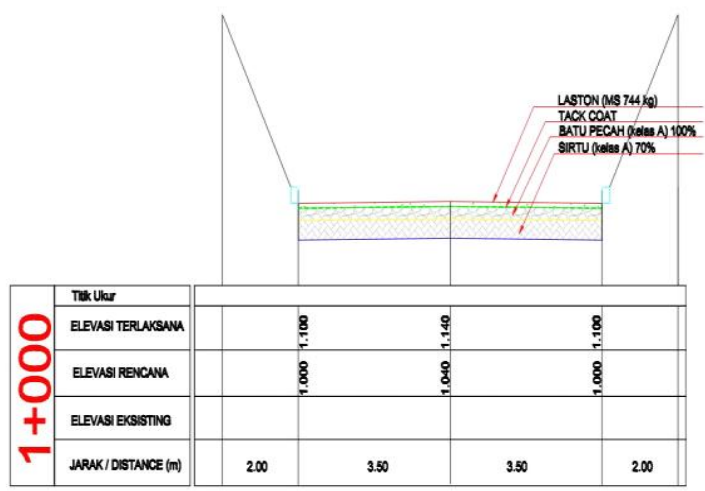

Gambar 4.14 Cross Section 1+000

- $\quad$ STA $1+000$

cc. Luas penampang $=t(b+k$.t)

dd. $k=\sqrt{B^{2}+t^{2}}$

ee. $k=\sqrt{2^{2}+2,7^{2}}$

ff. $k=3,36$

$\mathrm{L}=\mathrm{t}(\mathrm{b}+\mathrm{k} \cdot \mathrm{t})$

$\mathrm{L}=2,7(7+3,36$. 2,7)

$\mathrm{L}=43,39 \mathrm{~m}$

- $\quad$ STA $1+050(\mathrm{~L}=43,39 \mathrm{~m})$

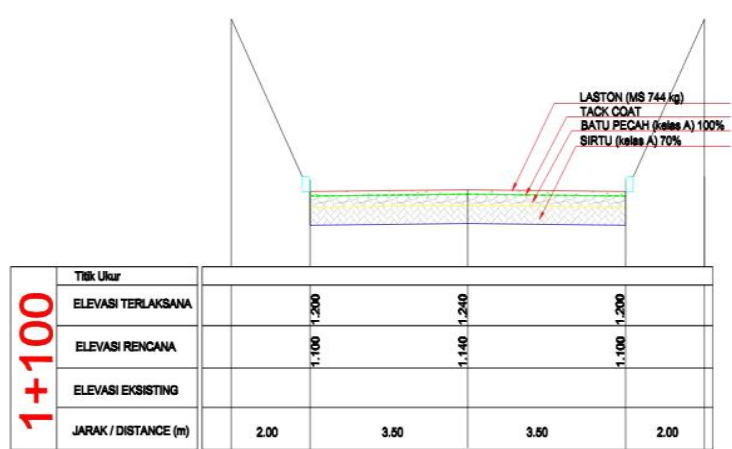

- $\quad$ STA $1+100$

gg. Luas penampang $=t(b+k \cdot t)$

$\begin{array}{ll}\text { hh. } & k=\sqrt{B^{2}+t^{2}} \\ \text { ii. } & k=\sqrt{2^{2}+3,32^{2}} \\ \text { ji. } & k=3,88\end{array}$

$\mathrm{ij}$.

$\mathrm{L}=3,32(7+3,88$. 3,32)

$\mathrm{L}=65,96 \mathrm{~m}$ 
Tabel 4.4 Rekapitulasi perhitungan galian dan timbunan

\begin{tabular}{|c|c|c|c|c|c|}
\hline \multirow{2}{*}{ STA } & \multicolumn{2}{|c|}{ LUAS PENAMPANG $\left(\mathrm{m}^{2}\right)$} & \multirow{2}{*}{$\begin{array}{c}\text { JARAK } \\
\text { (m) }\end{array}$} & \multicolumn{2}{|c|}{ VOLUME $\left(\mathrm{m}^{3}\right)$} \\
\hline & GALAN & TIMBUNAN & & GAUAN & TIMBUNAN \\
\hline $0+000$ & 0.00 & 0.00 & 50 & \multirow{2}{*}{$\mathbf{0}$} & \multirow{2}{*}{$\mathbf{0}$} \\
\hline $0+050$ & 0.00 & 0.00 & 50 & & \\
\hline $0+100$ & 0.00 & 0.00 & 50 & \multirow{2}{*}{0} & \multirow{2}{*}{$\mathbf{0}$} \\
\hline $0+150$ & 0.00 & 0.00 & 50 & & \\
\hline $0+189.25$ & 0.00 & 0.00 & 50 & \multirow{2}{*}{0} & \multirow{2}{*}{0} \\
\hline $0+200$ & 0.00 & 0.00 & 50 & & \\
\hline $0+250$ & 0.00 & 0.00 & 50 & \multirow{2}{*}{$\mathbf{0}$} & \multirow{2}{*}{$\mathbf{0}$} \\
\hline $0+300$ & 0.00 & 0.00 & 50 & & \\
\hline $0+350$ & 0.00 & 0.00 & 50 & \multirow{2}{*}{$\mathbf{0}$} & \multirow{2}{*}{$\mathbf{0}$} \\
\hline $0+400$ & 0.00 & 0.00 & 50 & & \\
\hline $0+4324$ & 0.00 & 0.00 & 50 & \multirow{2}{*}{$\mathbf{0}$} & \multirow{2}{*}{$\mathbf{0}$} \\
\hline $0+450$ & 0.00 & 0.00 & 50 & & \\
\hline $0+500$ & 0.00 & 0.00 & 50 & \multirow{2}{*}{$\mathbf{0}$} & \multirow{2}{*}{$\mathbf{0}$} \\
\hline $0+550$ & 0.00 & 0.00 & 50 & & \\
\hline $0+600$ & 5.84 & 0.00 & 50 & \multirow{2}{*}{291.863752} & \multirow{2}{*}{$\mathbf{0}$} \\
\hline $0+650$ & 5.84 & 0.00 & 50 & & \\
\hline $0+700$ & 10.09 & 0.00 & 50 & \multirow{2}{*}{504.345239} & \multirow{2}{*}{$\mathbf{0}$} \\
\hline $0+750$ & 10.09 & 0.00 & 50 & & \\
\hline $0+793.78$ & 1370 & 0.00 & 50 & \multirow{2}{*}{$8 \pi .817172$} & \multirow{2}{*}{0} \\
\hline $0+800$ & 21.13 & 0.00 & 50 & & \\
\hline $0+850$ & 21.13 & 0.00 & 50 & \multirow{2}{*}{$1 \times 67.10822$} & \multirow{2}{*}{0} \\
\hline $0+900$ & 29.55 & 0.00 & 50 & & \\
\hline $0+950$ & 29.55 & 0.00 & 50 & \multirow{2}{*}{1823.73032} & \multirow{2}{*}{0} \\
\hline $0+1000$ & 43.39 & 0.00 & 50 & & \\
\hline $0+1050$ & 43.39 & 0.00 & 50 & \multirow{2}{*}{2733.90671} & \multirow{2}{*}{0} \\
\hline $0+1100$ & 65.96 & 0.00 & 50 & & \\
\hline total & 299.67 & 0.00 & 1300 & 7491.77 & 0 \\
\hline
\end{tabular}

Sumber : Pengolahan Data

\section{Pengolahan Data Perkerasan Jalan}

Data yang dipergunakan dalam perencanaan tebal perkerasan ini diperoleh dari referensi dosen pembimbing dengan pendekatan data pada lokasi tempat studi kasus penelitian ialah

- Fungsi Jalan $=$ Arteri kelas IIIA (MST 10ton)

- $\quad$ Jalan dibuka pada tahun $=2017$

- Pertumbuhan lalu lintas selama pelaksaaan $=2 \%$

- Pertumbuhan lalu lintas selama umur rencana $=6 \%$

- Umur rencana (UR) = 10 tahun

- Curah hujan rata-rata = $>900 \mathrm{~mm} /$ tahun, termasuk pada iklim I

- Kelandaian $=<6 \%$

- Susunan lapis perkerasan Surface course = Laston MS 744

- Base course = Batu pecah $\mathrm{CBR}$ 100(kelas A)

- $\quad$ Sub base course $=$ Sirtu CBR $70($ kelas A)

Keterangan :

Keterangan : Panjang jarak Trase baru $1100 \mathrm{~m}$

$\mathrm{C}=$ (Koefisien distribusi kendaraan) didapat dari jumlah 2 jalur 1 arah
Tabel 4.5 Nilai LHR (1)

Arah Jakarta ( Puncak-Cipanas)

\begin{tabular}{|c|l|c|}
\hline no & \multicolumn{1}{|c|}{$\begin{array}{c}\text { kelompok } \\
\text { kendaraan }\end{array}$} & $\begin{array}{c}\text { LHR awal perencanaan } \\
\text { / LHR survei }\end{array}$ \\
\hline 1 & LHR 2016 \\
\hline 2 & mobil penumpang & 4976 \\
\hline 3 & pick up, combi & 5128 \\
\hline 4 & truk 2 as kecil & 864 \\
\hline 5 & truk 2 as besar & 272 \\
\hline 6 & truk 3 as tandem & 128 \\
\hline 7 & bus besar & 104 \\
\hline 8 & truk trailer 26,6 ton & 208 \\
\hline 9 & truk gandeng 4 as & 0 \\
\hline 10 & truk trailer 42 ton & 0 \\
\hline & Total & 0 \\
\hline &
\end{tabular}

Sumber : Survey

Tabel 4.6 Nilai LHR (2) Arah Cianjur (CipanasPuncak

\begin{tabular}{|c|l|c|}
\hline no & \multicolumn{1}{|c|}{$\begin{array}{c}\text { kelompok } \\
\text { kendaraan }\end{array}$} & $\begin{array}{c}\text { LHR awal perencanaan } \\
\text { / LHR survei }\end{array}$ \\
\hline 1 & mobil penumpang & LHR 2016 \\
\hline 2 & pick up, combi & 4784 \\
\hline 3 & truk 2 as kecil & 600 \\
\hline 4 & truk 2 as besar & 200 \\
\hline 5 & truk 3 as tandem & 144 \\
\hline 6 & bus besar & 184 \\
\hline 7 & bus kecil & 192 \\
\hline 8 & truk trailer 26,6 ton & 0 \\
\hline 9 & truk gandeng 4 as & 0 \\
\hline 10 & truk trailer 42 ton & 0 \\
\hline & Total & 10728 \\
\hline
\end{tabular}

Sumber :Survey

\section{Penentuan CBR Desain Tanah Dasar}

Harga CBR digunakan untuk menetapkan daya dukung tanah dasar (DDT), berdasarkan grafik korelasi DDT dan CBR. Yang dimaksud harga CBR disini adalahCBR lapangan atau CBR laboratorium.

Dari Data CBR yang terdapat didalam dokumen Dinas Binamarga Provinsi Jawa Barat, didapat Data nilai DCP CBR sebagai berikut : (STA Cianjur)

Tabel 4.7 Data CBR Tanah Dasar

\begin{tabular}{|l|c|c|c|c|c|c|c|c|}
\hline Sta & $21+700$ & $22+200$ & $22+300$ & $22+600$ & $22+900$ & $23+000$ & $23+100$ & $23+300$ \\
\hline CBR $(\%)$ & 1.41 & 2.36 & 2.22 & 2.71 & 3.49 & 2.85 & 4.77 & 2.16 \\
\hline \multicolumn{10}{c|}{ Sumber : Dinas Binamarga Provinsi Jawa }
\end{tabular}
Barat 
Tabel 4.8 Perhitungan jumlah dan prosentase CBR yang sama atau lebih besar

\begin{tabular}{|c|c|c|l|}
\hline NO & CBR & $\begin{array}{c}\text { jmlh yg sama atau lebih } \\
\text { besar }\end{array}$ & \% yg sama atau lebih besar \\
\hline 1 & 1.41 & 8 & $8 / 8 \times 100=100 \%$ \\
\hline 2 & 2.16 & 7 & $7 / 8 \times 100=87.5 \%$ \\
\hline 3 & 2.22 & 6 & $6 / 8 \times 100=75 \%$ \\
\hline 4 & 2.36 & 5 & $5 / 8 \times 100=62.5 \%$ \\
\hline 5 & 2.71 & 4 & $4 / 8 \times 100=50 \%$ \\
\hline 6 & 2.85 & 3 & $3 / 8 \times 100=37.5 \%$ \\
\hline 7 & 3.49 & 2 & $2 / 8 \times 100=25 \%$ \\
\hline 8 & 4.72 & 1 & $1 / 8 \times 100=12.5 \%$ \\
\hline
\end{tabular}

Sumber : Hasil Pengolahan Data

Yang selanjutnya akan dibuat grafik penentuan CBR, antara CBR tanah dasar dengan persen yang sama atau lebih besar. Sehingga akan didapatkan nilai CBRnya. Yaitu nilai CBR 90\%.

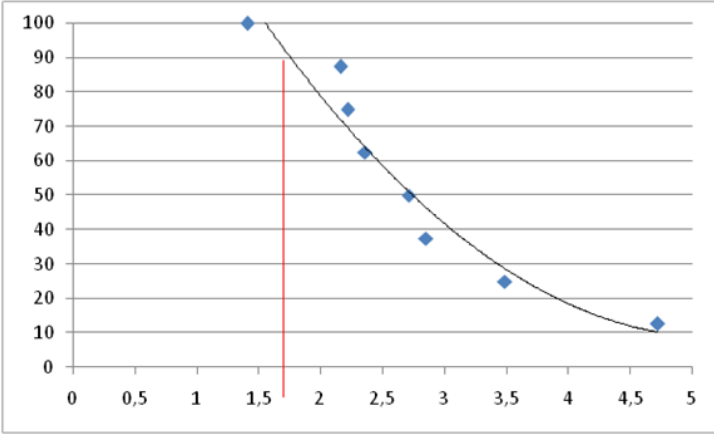

Gambar 4.16. Grafik hubungan CBR Tanah Dasar dengan Prosentase CBR yang sama atau lebih besar.

Sumber : Hasil Pengolahan Data

Setelah didapat perhitungan secara grafis maka didapat nilai CBR sebesar 1,75.

Selanjutnya daya dukung tanah akan dihitung berdasarkan nilai CBR yang telah didapat, dengan memakai rumus sebagai berikut :

$$
\begin{aligned}
\text { DDT } & =4,3 \log (\mathrm{CBR})+1,7=4,3 \log (1,75)+1,7 \\
& =2,75
\end{aligned}
$$

\section{Perhitungan Volume Lalu - Lintas}

b) Perhitungan Lalu Lintas Harian Rata-rata

> Jalan direncanakan tahun 2017 maka LHR yang dipakai LHR tahun 2016 dari tabel 4.4 dan tabel 4.5

> Jalan dibuka tahun 2017 maka LHR Awal Umur Rencana adalah LHR tahun 2016 dengan pertumbuhan lalu lintas $2 \%$, maka $\mathrm{i} 1=2 \%$ dan masa kontruksi $(\mathrm{n} 1)=1$

> Umur rencana adalah 10 tahun, maka LHR Akhir Umur Rencana adalah LHR tahun 2017 dengan pertumbuhan lalu lintas ( i2 ) $=6 \%$ dan umur rencana $(\mathrm{n} 2)=10$
Rumus LHR Awal Umur Rencana ( LHR 2017 ) : LHR2016(1 + i1) n1 Sumber : Buku Petunjuk Perencanaan Tebal Perkerasan Lentur Jalan Raya Dengan Metode Analisa Komponen SKBI 2.3.26.1987. Hal. 11

Tabel 4.9 Perhitungan Lalu Lintas Harian Ratarata (1) Arah Jakarta (Puncak-Cipanas)

\begin{tabular}{|c|l|c|c|c|}
\hline no & \multicolumn{1}{|c|}{$\begin{array}{c}\text { kelompok } \\
\text { kendaraan }\end{array}$} & $\begin{array}{c}\text { LHR awal } \\
\text { perencanaan } \\
\text { / LHR survei }\end{array}$ & $\begin{array}{c}\text { LHR awal umur } \\
\text { rencana } \\
\text { (LHR 2017) }\end{array}$ & $\begin{array}{c}\text { LHR akhir umur } \\
\text { rencana } \\
\text { (LHR 2027) }\end{array}$ \\
\hline & & LHR 2016 & LHR2016 (1+0,02)1 & LHR2017 (1+0,06)10 \\
\hline 1 & mobil penumpang & 4976 & 5075.52 & 9135.94 \\
\hline 2 & pick up, combi & 5128 & 5230.56 & 9415.01 \\
\hline 3 & truk 2 as kecil & 864 & 881.28 & 1586.30 \\
\hline 4 & truk 2 as besar & 272 & 277.44 & 499.39 \\
\hline 5 & truk 3 as tandem & 128 & 130.56 & 279.07 \\
\hline 6 & bus besar & 104 & 106.08 & 484.70 \\
\hline 7 & bus kecil & 208 & 212.16 & 381.89 \\
\hline 8 & truk trailer 26,6 ton & 0 & 0 & 0.00 \\
\hline 9 & truk gandeng 4 as & 0 & 0 & 0.00 \\
\hline 10 & truk trailer 42 ton & 0 & 0 & 0.00 \\
\hline & Total & 11680 & 11913.6 & 21782.30 \\
\hline
\end{tabular}

Sumber : Hasil Pengolahan Data

Tabel 4.10 Perhitungan Lalu Lintas Harian Ratarata (2) Arah Cianjur (Cipanas-Puncak)

\begin{tabular}{|c|l|c|c|c|}
\hline no & \multicolumn{1}{|c|}{$\begin{array}{c}\text { kelompok } \\
\text { kendaraan }\end{array}$} & $\begin{array}{c}\text { LHR awal } \\
\text { perencanaan } \\
\text { / LHR survei }\end{array}$ & $\begin{array}{c}\text { LHR awal umur } \\
\text { rencana } \\
\text { (LHR 2017) }\end{array}$ & $\begin{array}{c}\text { LHR akhir umur } \\
\text { rencana } \\
\text { (LHR 2027) }\end{array}$ \\
\hline & & LHR 2016 & LHR2016(1+0,02)1 & LHR2017 (1+0,06)10 \\
\hline 1 & mobil penumpang & 4784 & 4879.68 & 8783.42 \\
\hline 2 & pick up, combi & 4624 & 4716.48 & 8489.66 \\
\hline 3 & truk 2 as kecil & 600 & 612 & 1160.35 \\
\hline 4 & truk 2 as besar & 200 & 204 & 396.58 \\
\hline 5 & truk 3 as tandem & 144 & 146.88 & 264.38 \\
\hline 6 & bus besar & 184 & 187.68 & 337.82 \\
\hline 7 & bus kecil & 192 & 195.84 & 381.89 \\
\hline 8 & truk trailer 26,6 ton & 0 & 0 & 0.00 \\
\hline 9 & truk gandeng 4 as & 0 & 0 & 0.00 \\
\hline 10 & truk trailer 42 ton & 0 & 0 & 0.00 \\
\hline & Total & 10728 & 10942.56 & 19814.11 \\
\hline
\end{tabular}

Sumber : Hasil Pengolahan Data

\section{Perhitungan Angka Ekivalen (E) Masing- Masing Kendaraan}

Angaka Ekivalen (E) dari suatu sumbu kendaraan adalah angka yang menyatakan perbandingan tingkat kerusakan yang ditimbulkan oleh suatu lintasan beban sumbu tunggal kendaraan terhadap tingkat kerusakan yang ditimbulkan oleh satu lintasan beban standar sumbu tunggal seberat 8,16 ton $(18.000 \mathrm{lb})$.

Berdasarkan Buku Petunjuk Perencanaan Tebal Perkerasan Lentur Jalan Raya Dengan Metode Analisa Komponen SKBI 2.3.26.1987. Daftar III Angka Ekivalen (E) Beban Sumbu Kendaraan dapat dihitung sebagai berikut: 
Tabel 4.11Angka Ekivalen (E) Masing-Masing Kendaraan

\begin{tabular}{|c|l|c|c|c|}
\hline No & \multicolumn{1}{|c|}{ Jenis Kendaraan } & Depan & Belakang & Nilai E \\
\hline 1 & mobil penumpang (2 ton) & 0,0002 & 0,0002 & 0,0004 \\
\hline 2 & pick up, combi (4 ton) & 0,0007 & 0,011 & 0,0117 \\
\hline 3 & truk 2 as kecil (8,3 ton) & 0,0143 & 0,2031 & 0,2174 \\
\hline 4 & truk 2 as besar (18,2 ton) & 0,3307 & 46,957 & 50,264 \\
\hline 5 & truk 3 as tandem (25 ton) & 0,3441 & 23,975 & 27,416 \\
\hline 6 & bus besar (13,2 ton) & 0,0951 & 12,993 & 13,908 \\
\hline 7 & bus kecil (9 ton) & 0,0197 & 0,2808 & 0,3005 \\
\hline
\end{tabular}

\section{sumber : Pengolahan Data}

\section{Penentuan Koefisien Distribusi Kendaraan ( C)}

Berdasarkan Buku Petunjuk Perencanaan Tebal Perkerasan Lentur Jalan Raya Dengan Metode Analisa Komponen SKBI 2.3.26.1987. Daftar II Koefisien distribusi kendaraan ( $\mathrm{C}$ ) dapat diketahui nilai $\mathrm{C}$ yaitu :

Untuk 2 Lajur 1 Arah :

- Kendaraan Ringan $=0,60(<5$ Ton $)$

- Kendaraan Berat $=0,70$ ( $\geq 5$ Ton)

Yang termasuk dalam kategori kendaraan Ringan ( $<5$ Ton) dari analisa yaitu :

1. mobil penumpang ( 2 ton)

2. pick up, combi (4 ton)

Yang termasuk dalam kategori kendaraan Berat ( $\geq$ 5 Ton) dari analisa yaitu :

1. truk 2 as kecil (8,3 ton)

2. truk 2 as besar (18,2 ton)

3. truk 3 as tandem (25 ton)

4. bus besar (13,2 ton)

5. bus kecil (9 ton)

6. truk trailer 26,6 ton $(26,4$ ton)

7. truk gandeng 4 as $(31,4$ ton $)$

8. truk trailer 42 ton (42 ton )

\section{Perhitungan Lintas Ekivalen}

$>$ LEP (Lintas Ekivalen Permulaan) : Rumus LEP = C x E x LHR2017

$>$ LEA (Lintas Ekivalen Akhir) : Rumus LEA $=$ C x E x LHR2027

$>$ LET (Lintas Ekivalen Tengah) : Rumus LET $=1 / 2($ LEP + LEA $)$

$>$ LER (Lintas Ekivalen Rencana) :

Rumus LER $=$ LET $x^{\frac{U R}{10}}$

Sumber : Buku Petunjuk Perencanaan Tebal Perkerasan Lentur Jalan Raya Dengan

Metode Analisa Komponen SKBI 2.3.26.1987.
Tabel 4.12 Perhitungan Lintas Ekivalen (1) Arah Jakarta (Puncak-Cipanas)

\begin{tabular}{|c|c|c|c|c|c|}
\hline \multirow[b]{2}{*}{ No } & \multirow[b]{2}{*}{ Jenis Kendaraan } & LEP & LEA & LET & LER \\
\hline & & $\begin{array}{c}\text { CXEX } \\
\text { LHR } \\
2017\end{array}$ & $\begin{array}{c}\text { CXEX } \\
\text { LHR } \\
2027\end{array}$ & $\begin{array}{c}0,5 x \\
(\text { LEP+LEA) }\end{array}$ & $\begin{array}{c}\text { LET x } \\
(U R / 10)\end{array}$ \\
\hline 1 & mobil penumpang ( 2 ton) & 1.22 & 2.19 & 1.71 & 1.71 \\
\hline 2 & pick up, combi (4 ton) & 36.72 & 66.09 & 51.41 & 51.41 \\
\hline 3 & truk 2 as kecil ( 8,3 ton) & 114.95 & 241.40 & 178.18 & 178.18 \\
\hline 4 & truk 2 as besar ( 18,2 ton) & 836.71 & 1757.10 & 1296.91 & 1296.91 \\
\hline 5 & truk 3 as tandem ( 25 ton) & 255.03 & 535.57 & 395.30 & 395.30 \\
\hline 6 & bus besar (13,2 ton) & 224.71 & 471.89 & 348.30 & 348.30 \\
\hline 7 & bus kecil (9 ton) & 38.25 & 80.33 & 59.29 & 59.29 \\
\hline 8 & truk trailer 26,6 ton $(26,4$ ton) & 0.00 & 0.00 & 0.00 & 0.00 \\
\hline 9 & truk gandeng 4 as (31, 4 ton) & 0.00 & 0.00 & 0.00 & 0.00 \\
\hline 10 & truk trailer 42 ton (42 ton ) & 0.00 & 0.00 & 0.00 & 0.00 \\
\hline & TOTAL & 1507.60 & 3154.58 & 2331.09 & 2331.09 \\
\hline
\end{tabular}

Sumber : Hasil Pengolahan Data

Tabel 4.13 Perhitungan Lintas Ekivalen (2) Arah Cianjur(Cipanas-Puncak)

\begin{tabular}{|c|c|c|c|c|c|}
\hline \multirow[b]{2}{*}{ No } & \multirow[b]{2}{*}{ Jenis Kendaraan } & LEP & LEA & LET & LER \\
\hline & & $\begin{array}{c}\text { CXEX } \\
\text { LHR } \\
2017\end{array}$ & $\begin{array}{l}\text { CXEX } \\
\text { LHR } \\
2027\end{array}$ & $\begin{array}{c}0,5 x \\
\text { (LEP+LEA) }\end{array}$ & $\begin{array}{c}\text { LET X } \\
(U R / 10)\end{array}$ \\
\hline 1 & mobil penumpang ( 2 ton) & 1.17 & 2.11 & 1.64 & 1.64 \\
\hline 2 & pick up, combi (4 ton) & 33.11 & 59.60 & 46.35 & 46.35 \\
\hline 3 & truk 2 as kecil ( 8,3 ton) & 84.09 & 176.58 & 130.33 & 130.33 \\
\hline 4 & truk 2 as besar ( 18,2 ton) & 664.45 & 1395.34 & 1029.90 & 1029.90 \\
\hline 5 & truk 3 as tandem ( 25 ton) & 241.61 & 507.38 & 374.50 & 374.50 \\
\hline 6 & bus besar ( 13,2 ton) & 156.62 & 328.89 & 242.75 & 242.75 \\
\hline 7 & bus kecil (9 ton) & 38.25 & 80.33 & 59.29 & 59.29 \\
\hline 8 & truk trailer 26,6 ton $(26,4$ ton) & 0.00 & 0.00 & 0.00 & 0.00 \\
\hline 9 & truk gandeng 4 as (31, 4 ton) & 0.00 & 0.00 & 0.00 & 0.00 \\
\hline 10 & truk trailer 42 ton ( 42 ton ) & 0.00 & 0.00 & 0.00 & 0.00 \\
\hline & TOTAL & 1219.30 & 2550.24 & 1884.77 & 1884.77 \\
\hline
\end{tabular}

Sumber : Hasil Pengolahan Data

\section{Penentuan Indeks Tebal Perkerasan (ITP)}

Indeks tebal perkerasan dihitung berdasarkan datadata sebagai berikut :

1. CBR dan daya dukung tanah (DDT)

Setelah didapat perhitungan secara grafis maka didapat nilai CBR sebesar 1,75.

Selanjutnya daya dukung tanah akan dihitung berdasarkan nilai CBR yang telah didapat, dengan memakai rumus sebagai berikut :

$\mathrm{DDT}=4,3 \log (\mathrm{CBR})+1,7=4,3 \log (1,75)+1,7=$ 2,75

2. Indeks permukaan pada akhir umur rencana (IPT)

Untuk ruas jalan Puncak - Cipanas kab Cianjur KM 85-87 Bandung ini, dengan nilai LER sebagai berikut :

- Arah Jakarta (Puncak-Cipanas) = 2331.09

- Arah Cianjur (Cipanas-Puncak) = 1884.77 
Klasifikasi jalan termasuk jalan Kolektor (LER > 1000), maka dari tabel indeks permukaan akhir umur rencaba (IPt), (Departemen Pekerjaan Umum, Petunjuk Perencanaan Tabel Perekerasan Lentur Jalan Raya Dengan Metode Analisa Komponen SKBI-2.3.26.1987, UDC : 625.73 (02).1987), didapat nilai $(\mathrm{IPt})=2,0-2,5$

3. Indeks permukaan pada awal umur rencana (IPo)

Maka dari tabel indeks permukaan pada akhir umur rencana (IPo), (Departemen Pekerjaan Umum, Petunjuk Perencanaan Tabel Perekerasan Lentur Jalan Raya Dengan Methode Analisa Komponen SKBI-2.3.26.1987, UDC : 625.73 (02).1987), didapat nilai $\mathrm{IPo}=>4 \quad($ laston $\mathrm{ms} 744 \mathrm{~kg})$

Untuk IPt $=2,0-2,5$ dan IPo $=3,9-3,5$ digunakan nomogram 4 (Terlampir)

Dengan DDT 2,75

4. Faktor Regional (FR)

Iklim ( curah hujan ) dan presentase kendaraan berat.

Dengan diperoleh nilai curah hujan rata-rata tahunan Station Cianjur tahun 1980-2006 dari PSDA $<900 \mathrm{~mm} /$ tahun. Presentase kendaraan berat yang lewat pada ruas jalan Puncak - Cipanas kab Cianjur KM 85-87 Bandung kurang dari $30 \%$.

\section{- Arah Jakarta (Puncak-Cipanas) = $14,83 \%$ \\ - Arah Cianjur (Cipanas-Puncak) = $12,82 \%$}

Serta kelandaian pada ruas jalan Puncak - Cipanas kab Cianjur KM 85-87 Bandung kurang dari 6\% dengan menggunakan tabel faktor regional. (Departemen Pekerjaan Umum, Petunjuk Perencanaan Tabel Perekerasan Lentur Jalan Raya Dengan Methode Analisa Komponen SKBI2.3.26.1987, UDC : 625.73 (02).1987), didapat nilai $\mathrm{FR}=0,5$

11. Perhitungan Tebal Perkerasan

a) Perhitungan Tebal perkerasan jalan baru untuk ruas jalan arah Bogor Cianjur (Puncak-Cipanas)

Data perencanaan

Klasifikasi Jalan = pegunungan

- Fungsi Jalan = Arteri Kelas III A (MST) 10 ton)

- $\quad$ Tipe Jalan = 1 Jalur 2 Lajur 1 Arah (2/1 TB)

- Kecepatan Rencana (Vr) $=60 \mathrm{Km} / \mathrm{jam}$

- Lebar perkerasan $(\mathrm{w}) \quad=2 \times 3.5$ (7 meter)

- $\quad$ Bahu jalan $=2 \mathrm{~m}$

- Jari-jari minimum $=159$ (untuk Vr 60 $\mathrm{Km} / \mathrm{jam})$

- Panjang jalan $=1100$ meter

- Umur rencana 10 tahun

- $\quad$ Daya dukung tanah (DDT) $=2,75$

- $\quad$ LER = 2331.09

- $\quad \mathrm{FR}=0,5$

$$
\text { - } \quad \text { IPt }=2,0-2,5
$$$$
\text { - } \quad \mathrm{IPo}=3,9-3,5
$$

- Maka dengan menggunakan nomogram 4. (Departemen Pekerjaan Umum, Petunjuk Perencanaan Tabel Perekerasan Lentur Jalan Raya Dengan Methode Analisa Komponen SKBI-2.3.26.1987, UDC : 625.73 (02).1987), maka didapat nilai indeks tebal perkerasan $($ ITP $)=12,7$.

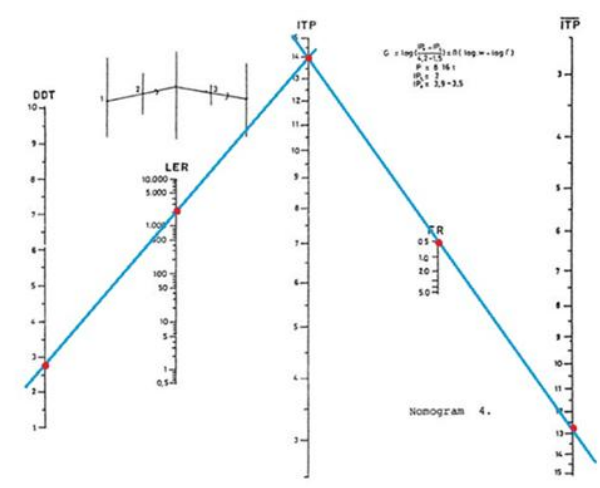

Gambar 4.17 Nomogram 4 (metode analisa komponen)

Menetapkan Tebal Perkerasan untuk jalan baru dari arah Bogor-Cianjur (Puncak-Cipanas), dari KM 8587 BDG, dengan umur rencana 10 tahun dan jenis jalan Kolektor. Digunakan rumus persamaan dari Methode Analisa Komponen SKBI-2.3.26.1987, UDC : 625.73 (02).1987), yaitu :

$$
I T P=a 1 . D 1+a 2 . D 2+a 3 . D 3
$$

Dipilih jenis lapis perkerasan yang terdiri dari :

- Koefisien kekuatan relative (a)

a1 = Laston MS 744

a2 = Batu Pecah (kelas A) CBR $100 \quad=0,14$

a3 = Sirtu (kelas A) CBR 70 =0,13

- Tebal Minimum masing-masing lapisan permukaan (D)

$\mathrm{D} 1=$ diperoleh ITP $12,7 \geq 10$ (Laston) $=10 \mathrm{~cm}$

D2 $=$ diperoleh ITP $12,7 \geq 12,25=25 \mathrm{~cm}$

$\mathrm{D} 3=$ minimum $=10 \mathrm{~cm}$

Perhitungan dengan mencoba nilai D1, D2, D3, diketahui nilai minimum

$$
\begin{array}{ll}
-\quad & \text { Nilai D1 dan D2 diketahui nilai minimum } \\
\text { ITP } & =\text { a1.D1 + a2.D2+ a3.D3 } \\
12,7 & =0,4 \cdot 10+0,14 \cdot 25+0,13 \cdot \mathrm{D} 3 \\
12,7 & =4+3,5+0,13 \cdot \mathrm{D} 3 \\
\text { D3 } & =12,7-(4+3,5) / 0,13=40 \mathrm{~cm}
\end{array}
$$




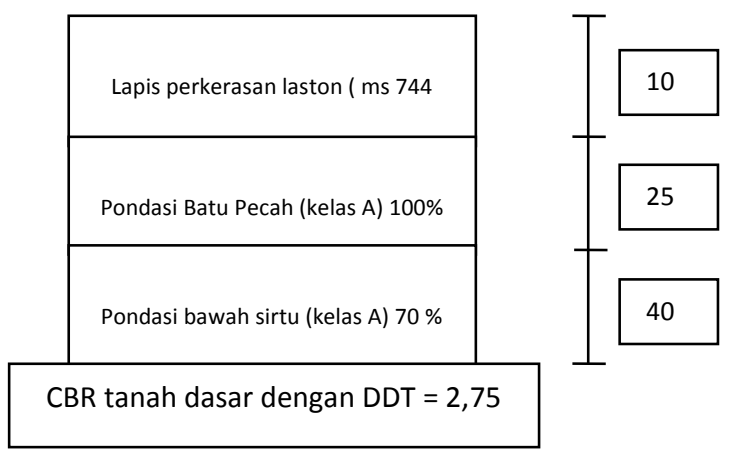

$$
\begin{array}{ll}
- & \text { Nilai D1 dan D3 diketahui nilai minimum } \\
\text { ITP } & =\text { a1.D1 + a2.D2+ a3.D3 } \\
12,7 & =0,4 \cdot 10+0,14 \cdot \mathrm{D} 2+0,13 \cdot 10 \\
12,7 & =4+0,14 . \mathrm{D} 2+1,3 \\
\text { D2 } & =12,7-(4+1,5) / 0,14=51,42 \approx 52 \mathrm{~cm}
\end{array}
$$

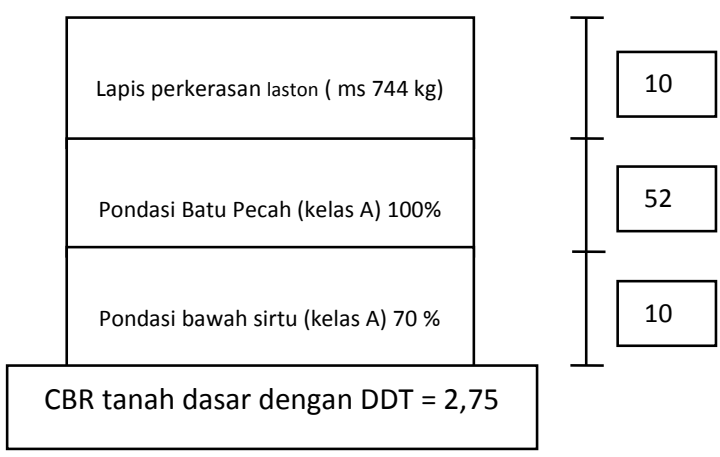

$$
\begin{array}{ll}
- & \text { Nilai D2 dan D3 diketahui nilai minimum } \\
\text { ITP } & =\text { a } 1 . \mathrm{D} 1+\mathrm{a} 2 . \mathrm{D} 2+\mathrm{a} 3 . \mathrm{D} 3 \\
12,7 & =0,4 \cdot \mathrm{D} 1+0,14 \cdot 25+0,13 \cdot 10 \\
12,7 & =0,4 \cdot \mathrm{D} 1+3,5+1,3 \\
\mathrm{D} 1 & =12,7-(3,5+1,3) / 0,4=19,75 \approx 20 \mathrm{~cm}
\end{array}
$$

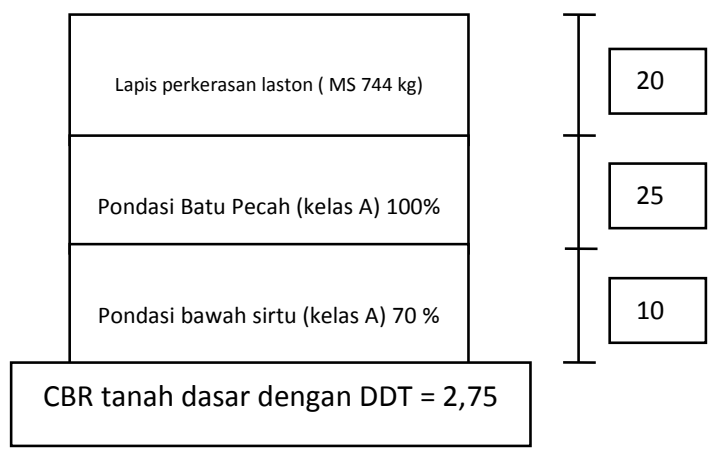

Dipakai lapis perkerasan untuk perencanaan perkerasan jalan lentur untuk jalan trase baru arah Bogor - Cianjur (Puncak-Cipanas), dengan memaksimalkan lapis pondasi bawah,guna mencapai efisiensi penggunaan material yang relatif murah agar lapisan- lapisan di atasnya dapat dikurangi ketebalannya (penghematan biaya konstruksi), yaitu :

- $\quad$ Nilai D1 dan D2 diketahui nilai minimum

ITP $=\mathrm{a} 1 . \mathrm{D} 1+\mathrm{a} 2 . \mathrm{D} 2+\mathrm{a} 3 . \mathrm{D} 3$

$12,7=0,4 \cdot 10+0,14 \cdot 25+0,13 \cdot \mathrm{D} 3$
$12,7=4+3,5+0,13 . \mathrm{D} 3$

D3 $=12,7-(4+3,5) / 0,13=40 \mathrm{~cm}$

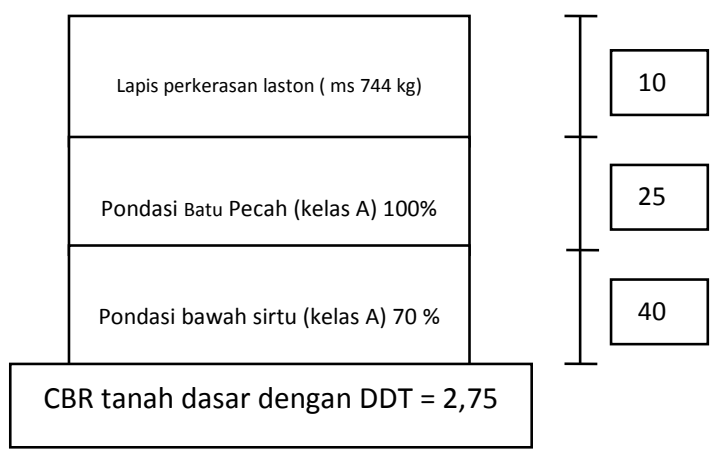

D. KESIMPULAN

a. Kesimpulan

1. Berdasarkan hasil survey volume kendaraan pada ruas jalan Cipanas Puncak KM Bandung 85-87 Kab Cianjur Provinsi Jawa Barat yang didapat dari hasil survey dengan data lalu lintas harian ratarata sebagai berikut :

- Arah Jakarta ( Puncak-Cipanas )

\begin{tabular}{|c|l|c|}
\hline no & $\begin{array}{c}\text { kelompok } \\
\text { kendaraan }\end{array}$ & $\begin{array}{c}\text { LHR awal perencanaan } \\
\text { / LHR survei }\end{array}$ \\
\hline 1 & mobil penumpang & 4976 \\
\hline 2 & pick up, combi & 5128 \\
\hline 3 & truk 2 as kecil & 864 \\
\hline 4 & truk 2 as besar & 272 \\
\hline 5 & truk 3 as tandem & 128 \\
\hline 6 & bus besar & 104 \\
\hline 7 & bus kecil & 208 \\
\hline 8 & truk trailer 26,6 ton & 0 \\
\hline 9 & truk gandeng 4 as & 0 \\
\hline 10 & truk trailer 42 ton & 0 \\
\hline & Total & 11680 \\
\hline & \multicolumn{2}{|c|}{} \\
\hline
\end{tabular}

- $\quad$ Arah Cianjur ( Cipanas-Puncak )

\begin{tabular}{|c|l|c|}
\hline no & $\begin{array}{c}\text { kelompok } \\
\text { kendaraan }\end{array}$ & $\begin{array}{c}\text { LHR awal perencanaan } \\
\text { / LHR survei }\end{array}$ \\
\hline & LHR 2016 \\
\hline 1 & mobil penumpang & 4784 \\
\hline 2 & pick up, combi & 4624 \\
\hline 3 & truk 2 as kecil & 600 \\
\hline 4 & truk 2 as besar & 200 \\
\hline 5 & truk 3 as tandem & 144 \\
\hline 6 & bus besar & 184 \\
\hline 7 & bus kecil & 192 \\
\hline 8 & truk trailer 26,6 ton & 0 \\
\hline 9 & truk gandeng 4 as & 0 \\
\hline 10 & truk trailer 42 ton & 0 \\
\hline & Total & 10728 \\
\hline
\end{tabular}

2. Ruas jalan Cipanas - Puncak KM Bandung85-87 Kab Cianjur Provinsi Jawa Barat dibuat trase jalan baru dengan jenis jalan baru yang direncanakan merupakan 
jalan arteri dengan spesifikasi lebar perkerasan $2 \times 3,5$ meter, dengan kecepatan rencana $60 \mathrm{~km} / \mathrm{jam}$, direncanakan 3 tikungan ( 2 tikungan Spiral-Circle-Spiral dan 1 tikungan Full Circle).

a) Pada tikungan P1 dengan jari-jari Lengkung rencana 179 meter, dengan sudut sebesar $53^{\circ}$ direncanakan menggunakan tikungan Spiral-CircleSpiral ( S - C - S )

b) Pada tikungan P2 dengan jari-jari Lengkung rencana 500 meter, dengan sudut sebesar $47^{\circ}$ direncanakan menggunakan tikungan Full Circle ( $\mathrm{F}-\mathrm{C}$ )

c) Pada tikungan P3 dengan jari-jari Lengkung rencana 159 meter, dengan sudut sebesar $58^{\circ}$ direncanakan menggunakan tikungan Spiral-CircleSpiral ( $\mathrm{S}-\mathrm{C}-\mathrm{S}$ )

3. Pada alinemen vertikal jalan baru yang ditinjau terdapat 3 PVV. Dengan hasil perhitungan elevasi sebagai berikut Umur Masa Layanan Perkerasan Kaku bisa bertahan sampai 20 Tahun.

\begin{tabular}{|l|c|}
\hline \multicolumn{1}{|c|}{ STA } & $\begin{array}{c}\text { ELEASI VERTICAL } \\
(\mathrm{m})\end{array}$ \\
\hline $0+050$ & 1159.87 \\
\hline $0+100$ & 1156.14 \\
\hline $0+150$ & 1153.41 \\
\hline $0+189.25$ & 1151.96 \\
\hline $0+200$ & 1148.09 \\
\hline $0+250$ & 1152.62 \\
\hline $0+300$ & 1158.64 \\
\hline $0+350$ & 1192.09 \\
\hline $0+400$ & 1185.81 \\
\hline $0+432,4$ & 1182.27 \\
\hline $0+450$ & 1182.00 \\
\hline $0+500$ & 1189.79 \\
\hline $0+550$ & 1211.49 \\
\hline $0+584,8$ & 1207.81 \\
\hline $0+600$ & 1208.89 \\
\hline $0+650$ & 1215.54 \\
\hline $0+700$ & 1233.09 \\
\hline $0+743,78$ & 1227.37 \\
\hline $0+750$ & 1228.29 \\
\hline $0+800$ & 1234.68 \\
\hline $0+850$ & 1270.64 \\
\hline $0+890$ & 1418.98 \\
\hline $0+900$ & 1263.46 \\
\hline $0+950$ & 1275.43 \\
\hline $1+000$ & 1286.36 \\
\hline $1+025,77$ & 1283.15 \\
\hline $1+050$ & 1287.63 \\
\hline $1+100$ & 1293.62 \\
\hline $1+150$ & 1300.61 \\
\hline & \\
\hline
\end{tabular}

4. Adapun hasil perhitungan galian dan timbunan disajikan dengan rekapitulasi sebagai berikut :

\begin{tabular}{|c|c|c|c|c|c|}
\hline \multirow{2}{*}{ STA } & \multicolumn{2}{|c|}{ LUASPENAMPANG $\left(\mathrm{m}^{2}\right)$} & \multirow{2}{*}{$\begin{array}{c}\text { JARAK } \\
\text { (m) }\end{array}$} & \multicolumn{2}{|c|}{ VOLUME $\left(\mathrm{m}^{3}\right)$} \\
\hline & GAUAN & TIMBUNAN & & GALAN & TIMBUNAN \\
\hline $0+000$ & 0.00 & 0.00 & 50 & \multirow{2}{*}{$\mathbf{0}$} & \multirow{2}{*}{$\mathbf{0}$} \\
\hline $0+050$ & 0.00 & 0.00 & 50 & & \\
\hline $0+100$ & 0.00 & 0.00 & 50 & \multirow{2}{*}{0} & \multirow{2}{*}{$\mathbf{0}$} \\
\hline $0+150$ & 0.00 & 0.00 & 50 & & \\
\hline $0+189.25$ & 0.00 & 0.00 & 50 & \multirow{2}{*}{0} & \multirow{2}{*}{$\mathbf{0}$} \\
\hline $0+200$ & 0.00 & 0.00 & 50 & & \\
\hline $0+250$ & 0.00 & 0.00 & 50 & \multirow{2}{*}{0} & \multirow{2}{*}{$\mathbf{0}$} \\
\hline $0+300$ & 0.00 & 0.00 & 50 & & \\
\hline $0+350$ & 0.00 & 0.00 & 50 & \multirow{2}{*}{0} & \multirow{2}{*}{$\mathbf{0}$} \\
\hline $0+400$ & 0.00 & 0.00 & 50 & & \\
\hline $0+4324$ & 0.00 & 0.00 & 50 & \multirow{2}{*}{0} & \multirow{2}{*}{$\mathbf{0}$} \\
\hline $0+450$ & 0.00 & 0.00 & 50 & & \\
\hline $0+500$ & 0.00 & 0.00 & 50 & \multirow{2}{*}{0} & \multirow{2}{*}{0} \\
\hline $0+550$ & 0.00 & 0.00 & 50 & & \\
\hline $0+600$ & 5.84 & 0.00 & 50 & \multirow{2}{*}{291.863752} & \multirow{2}{*}{0} \\
\hline $0+650$ & 5.84 & 0.00 & 50 & & \\
\hline $0+700$ & 10.09 & 0.00 & 50 & \multirow{2}{*}{504.345239} & \multirow{2}{*}{$\mathbf{0}$} \\
\hline $0+750$ & 10.09 & 0.00 & 50 & & \\
\hline $0+793.78$ & 13.70 & 0.00 & 50 & \multirow{2}{*}{870.817172} & \multirow{2}{*}{$\mathbf{0}$} \\
\hline $0+800$ & 21.13 & 0.00 & 50 & & \\
\hline $0+850$ & 21.13 & 0.00 & 50 & \multirow{2}{*}{1267.10822} & \multirow{2}{*}{ o } \\
\hline $0+900$ & 29.55 & 0.00 & 50 & & \\
\hline $0+950$ & 29.55 & 0.00 & 50 & \multirow{2}{*}{1823.73032} & \multirow{2}{*}{0} \\
\hline $0+1000$ & 43.39 & 0.00 & 50 & & \\
\hline $0+1050$ & 43.39 & 0.00 & 50 & \multirow{2}{*}{2733.90671} & \multirow{2}{*}{0} \\
\hline $0+1100$ & 65.96 & 0.00 & 50 & & \\
\hline total & 299.67 & 0.00 & 1300 & 7491.77 & 0 \\
\hline
\end{tabular}

5. Perkerasan jalan pada ruas jalan Cipanas Puncak KM Bandung 85-87 Kab Cianjur Provinsi Jawa Barat menggunakan jenis perkerasan lentur berdasarkan volume LHR yang ada dengan :

Jenis bahan dan tebal lapisan perkerasan jalan baru digunakan :

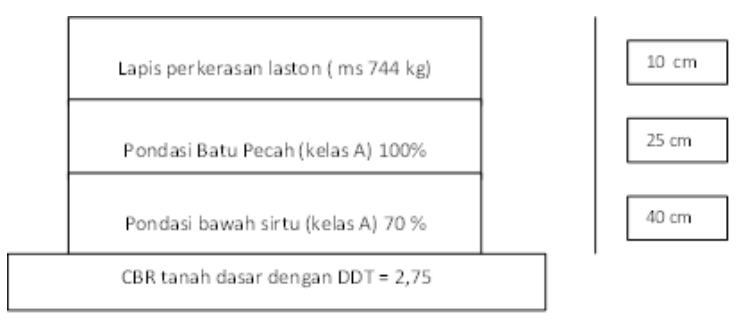

6. Perkerasan jalan baru sepanjang 1.100 meters

\section{b. Saran}

1. Perencanaan jalan ini diharapkan bisa dipakai dan direkomendasikan untuk dilaksanakan oleh instansi terkait dengan tujuan untuk mengurangi berbagai permasalahan yang terjadi diruas jalan Cipanas - Puncak KM Bandung 85-87 Kab Cianjur Provinsi Jawa Barat

2. Perencanaan jalan ini bisa djadikan kembali bahan Tugas Akhir bagi mahasiswa lain dengan meninjau dari segi analisis lainnya seperti Rencana Anggaran Biaya. 
3. Survey lapangan merupakan faktor yang penting sebelum melakukan suatu analisa geometric dan perkerasan jalan.

4. Diperlukan ketelitian dan kecermatan dalam melakukan analisa perkerasan dan diperlukan data-data yang cukup sebagai bahan analisa.

5. Detail gambar potongan harus lengkap agar mempermudah proses analisis perhitungan.

\section{E. DAFTAR PUSTAKA}

Adi. J, Putra, 2013, Perencanaan Geometrik Jalan Raya dan Tebal Lapis Perkerasan Lentur Dengan Menggunakan Metode Analisa Komponen Pada Proyek Peningkatan Jalan Sei Rampah-Tanjung Beringin.

Ageunk, Perkasa, 2015, Desain Alternatif Perencanaan Geometrik Dan Perkerasan Jalan Pada Ruas Jalan Bangbayang - Gekbrong Km Bandung 7479 Kab.Cianjur Provinsi Jawa Barat.

Bina MArga Dept. Pekerjaan Umum. No. 038/T/BM/1997 Ditjen, Tata Cara Perencanaan Geometrik Jalan Antar Kota.

Departemen Pekerjaan Umum, 1989, Tata Cara Perencanaan Tebal Perkerasan Lentur Jalan Raya Dengan Metode Analisa Komponen, SNI 1732-1989-F

Departemen Pekerjaan Umum, 1997,

Tata CaraPerencanaan Geometrik Jalan Antar Kota, No.038/TBM/1997

http://Perencanaan Geometrik Jalan Raya benhamcivil.htm.Diakses pada tanggal $\overline{7}$ Januari 2014.

Departemen Pekerjaan Umum, MKJI Tahun 1997 http://dokumen.tips/documents/potonganmelintang_ benhamcivil.htm.Diakses pada tanggal 7 Februari 2016.

Ilham, Ir, MT, Transportasi 1, Bahan Ajar Kuliah Teknik Sipil Univ. Suryakancana,.

Lauwtjunji.weebly.com/survey-dan-pengukuranawal-preliminnary-survey.html.Diakses pada tanggal April 2016.

Lembaga Penelitian-Universitas Terbuka, 2003, Studi Eksploratif Pendapatan Asli Daerah (PAD) Kabupaten Cianjur.

Pipinsupriatna21.blogspo.co.id/2013/04/membuatcross-section-bag-2.html.

Perencanaan Perkerasan Jalan Beton Semen, (2003) Departemen Pemukiman dan Prasarana Wilayah

Silvia Sukirman, Dasar-dasar Perencanaan Geometrik Jalan

Supiani. R, Asep, 2014, Evaluasi Perencanaan Geometrik dan Tebal Perkerasan Jalan Pada Ruas Jalan Cibadak-Cikidang-Pelabuhan Ratu Kabupaten Sukabumi, Cianjur.

Undang-undang No. 38 tahun 2004 tentang Jalan

Widhianto Bahtiar, 2010, Perencanaan Geomerti,Tebal Perkerasan,Anggaran Biaya dan Rencana Kerja Jalan Dawung-Koripan, Tugas Akhir Program Diploma III Teknik Sipil Transportasi Fakultas Teknik Universitas Sebelas Maret Surakarta. 